\title{
LIPIDOME FEATURES IN PATIENTS WITH DIFFERENT PROBABILITY OF FAMILY HYPERCHOLESTEROLEMIA
}

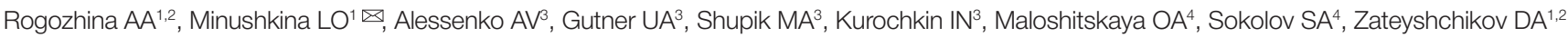

${ }^{1}$ Central State Medical Academy under the Administrative Department of the President of the Russian Federation, Moscow, Russia

${ }^{2}$ City Clinical Hospital № 51, Moscow, Russia

${ }^{3}$ Institute for Biochemical Physics, Moscow, Russia

${ }^{4}$ Lomonosov Moscow State University, Moscow, Russia

Development of modern methods for metabolome assessment, such as gas chromatography-mass spectrometry, allows one to expand the knowledge about the features of lipid metabolism in various clinical conditions. The study was aimed to investigate lipidome features in patients with different probability of family hypercholesterolemia (FH). The study involved 35 patients: 15 men (42.9\%) and 20 women (57.1\%) with dislipidemia or early cardiovascular diseases which manifested below 55 in men and 60 in women (average age of patients was $49.8 \pm 9.96$ ). The family dislipidemia probability was evaluated using the Dutch Lipid Clinic Network Score. In 10 patients the probability of FH was low (score 1-2), 22 patients had possible FH (score 3-5). Three patients had probable or definite FH (score 6 in 2 patients, score 9 in one patient). Determination of molecular species of sphingomyelins, ceramides and sphingoid bases (sphingosine, sphinganine) as well as galactosylceramide was carried out using gas chromatography-mass spectrometry. In patients with definite/probable FH the sphingosine level was significantly higher compared with patients having low probability of $\mathrm{FH}(144.36 \pm 107.863$ and $50.14 \pm 62.409 \mathrm{ng} / \mathrm{ml} ; p=0.01)$. In patients with $\mathrm{FH}$, an increase in the proportion of long chain sphingomyelin SM $18: 1 / 22: 0$ as well as a significant increase in the level of long chain ceramides with $C 20: 1$ and $C 22: 1$ was determined. Positive correlation of low-density lipoproteins and sphingosine level ( $r=0.344 ; p=0.047$ ) together with negative correlation of high-density lipoproteins (HDL), sphinganine $(r=-0.52 ; p=0.002)$, and galactosylceramide level $(r=-0.56 ; p=0.001)$ were detected. Thus, in patients with high probability of $\mathrm{FH}$ the lipidome changes were observed, which could be considered the cardiovascular risk markers.

Keywords: atherosclerosis, family hyperlipidemia, sphingomyelins, sphingosine, ceramides, risk marker

Funding: RFBR grant 19-04-00870A Sphingolipidome Analysis of Cardiovascular Diseases' Markers.

Author contribution: Rogozhina AA — sampling, data acquisition; Minushkina LO — data analysis, text writing; Zateyshchikov DA — planning, data analysis, manuscript writing; Alessenko AV — project manager; Gutner UA, Shupik MA, Maloshitskaya OA and Sokolov SA — sample preparation, laboratory analysis, data analysis; Kurochkin IN — data analysis.

Compliance with ethical standards: the study was approved by the Local Ethics Committee of City Clinical Hospital № 51 (protocol № 02/19 dated February 7 , 2019). Informed consent was obtained from all study participants.

$\triangle$ Correspondence should be addressed: Larisa O. Minushkina

Filevsky Boulevard, 36-19, Moscow, 121601; minushkina@mail.ru

Received: 30.11.2019 Accepted: 18.12.2019 Published online: 26.12.2019

DOI: $10.24075 / \mathrm{brsmu} .2019 .090$

\section{ОСОБЕННОСТИ ЛИПИДОМА У БОЛЬНЫХ С РАЗЛИЧНОЙ КЛИНИЧЕСКОЙ ВЕРОЯТНОСТЬЮ СЕМЕЙНОЙ ГИПЕРЛИПИДЕМИИ}

А. А. Рогожина ${ }^{1,2}$, Л. О. Минушкина ${ }^{1}$, А. В. Алесенко ${ }^{3}$ У. А. Гутнер ${ }^{3}$, М. А. Шупик ${ }^{3}$ И. Н. Курочкин ${ }^{3}$, О. А. Малошицкая ${ }^{4}$, С. А. Соколов ${ }^{4}$ Д. А. Затейщиков ${ }^{1,2}$

1 Центральная государственная медицинская академия Управления делами Президента Российской Федерации, Москва, Россия

2 Городская клиническая больница № 51, Москва, Россия

${ }^{3}$ Институт биохимической физики имени Н. М. Эмануэля РАН, Москва, Россия

${ }^{4}$ Московский государственный университет имени М. В. Ломоносова, Москва, Россия

Разработка современных методов оценки метаболома, таких как хромато-масс-спектрометрия, позволяет существенно расширить представления о липидном обмене в конкретных клинических ситуациях. Целью исследования было изучить особенности липидома у больных с различной вероятностью семейной гиперхолестеринемии (СГХС). В исследовании приняли участие 35 пациентов - 15 мужчин (42,9\%) и 20 женщин (57,1\%) с дислипидемией или ранними сердечно-сосудистыми заболеваниями, развившимися в возрасте до 55 лет у мужчин и до 60 лет у женщин. Средний возраст пациентов составил 49,8 \pm 9,96 лет. Вероятность семейной дислипидемии оценивали по критериям сети голландских липидных клиник. У 10 пациентов вероятность СГХС оценивали как низкую (1-2 балла), у 22 пациентов диагноз расценивали как вероятную СГХС (3-5 баллов). У 3 пациентов присутствовала возможная или определенная СГХС (2 пациента - 6 баллов, один пациент - 9 баллов). Определение молекулярных видов сфингомиелинов, церамидов и сфингоидных оснований (сфингозина, сфинганина), а также галактозоцерамида проводили методом хроматомасс-спектрометрии. Пациенты с определенной/вероятной СГХС имели достоверно более высокий уровень сфингозина по сравнению с пациентами с низкой клинической вероятностью СГХС (144,36 \pm 107,863 и 50,14 \pm 62,409 нг/мл; $p=0,01)$. В случае семейной СГХС отмечали увеличение доли длинноцепочечного сфингомиелина SM $18: 1 / 22: 0$ и существенное увеличение уровня церамидов с длинной углеродной цепью C 20 : 1 и С $22: 1$. Была выявлена значимая прямая корреляция уровня липопротеинов низкой плотности (ЛНП) и сфингозина $(r=0,344 ; p=0,047)$ наряду с обратными корреляциями уровня липопротеинов высокой плотности (ЛВП), сфинганина $(r=-0,52 ; p=0,002)$ и галактозилцерамида ( $r=-0,56 ; p=0,001)$. Таким образом, у пациентов с высокой клинической вероятностью СГХС были выявлены изменения липидома, являющиеся маркерами риска сердечнососудистых осложнений.

Ключевые слова: атеросклероз, семейная гиперлипидемия, сфингомиелины, сфингозин, церамиды, маркеры риска Финансирование: грант РФФИ 19-04-00870А «Сфинголипидомный анализ маркеров сердечно-сосудистых заболеваний».

Информация о вкладе авторов: А. А. Рогожина - отбор материала, сбор данных; Л. О. Минушкина - анализ полученных данных, написание статьи Д. А. Затейщиков - планирование работы, анализ данных, подготовка публикации; А. В. Алесенко - руководитель проекта; У. А. Гутнер, М. А. Шупик, О. А. Малошицкая и С. А. Соколов - пробоподготовка, проведение лабораторных исследований, анализ данных; И. Н. Курочкин - анализ данных.

Соблюдение этических стандартов: исследование одобрено этическим комитетом ГБУЗ «Городская клиническая больница № 51 ДЗМ» (протокол № 02/19 от 7 февраля 2019 г.). Все пациенты подписали добровольное информированное согласие на участие в исследовании.

Для корреспонденции: Минушкина Лариса Олеговна

Филевский б-р, 36-19, г. Москва, 121601; minushkina@mail.ru

Статья получена: 30.11.2019 Статья принята к печати: 18.12.2019 Опубликована онлайн: 26.12.2019

DOI: 10.24075/vrgmu.2019.090 
Lipid metabolism disorders, including the hereditary ones, are a key risk factor for atherosclerosis and its complications. The development of newest metabolome investigation methods, such as gas chromatography-mass spectrometry, allows one to expand the knowlege about the features of lipid metabolism in various clinical situations.

It was found that sphingolipids (sphingomyelins, ceramides, sphingosine, sphinganine sphingosine-1-phosphate (S1P) etc.) can play a significant role [1]. A change in the ratio of various sphingolipids is detected in patients affected with certain metabolic, genetic and autoimmune diseases (Fabry disease, Niemann-Pick diseases, Gaucher disease etc., some types of epilepsy, migraine, Alzheimer's disease).

An active study of the lipidome features associated with cardiovascular diseases is currently carried out. The prognostic value of some lipid fractions, mainly ceramides, in acute coronary syndrome has been revealed. The ratios of ceramides C 16: 0, C 20 : 0, C $24: 1$ and their relationship к C $24: 0$ are considered as possible risk markers.

The prognostic value of ceramides was evaluated in prospective studies. The ceramides' level was determined in patients with acute coronary syndrome [2]. It was found that the level of sphingomyelins, sphingosine, sphingazine-1- phosphate and ceramides can differ significantly in patients with acute and chronic forms of coronary heart disease [3].

At the same time, the lipidome features in patients with hereditary dislipidemia have not been studied. There are still no convincing data on the dynamics of the level of sphingolipids and ceramides against the background of lipid-lowering therapy. There are only single cases of comparison of the level of sphingolipids in patients without therapy and in patients receiving the lipid-lowering therapy $[4,5]$.

The study was aimed to investigate the features of sphingolipids in patients with different probability of family hypercholesterolemia.

\section{METHODS}

The study was carried out at the City Clinical Hospital № 51 in March-October 2019. Thirty five patients were surveyed. In the group of patients under study there were 15 men (42.9\%) and 20 women (57.1\%), average age was $49.8 \pm 9.96$. Inclusion criteria: early manifestations of atherosclerosis (coronary heart disease, peripheral artery disease or cerebrovascular disease with the age of onset below 55 in men and 60 in women, and/or dislipidemia ( $\mathrm{LDL}>4,9 \mathrm{mmol} / \mathrm{l})$. Exclusion criteria:

Table 1. Lipids and sphingolipids level in patiens with different probability of family hyperlipidemia

\begin{tabular}{|c|c|c|c|c|}
\hline \multirow{2}{*}{ Parameters } & $\begin{array}{l}\text { Unlikely FH } \\
\quad(n=10)\end{array}$ & $\begin{array}{l}\text { Probable FH } \\
\qquad(n=22)\end{array}$ & $\begin{array}{c}\text { Possible/definite } \mathrm{FH} \\
\qquad(n=3)\end{array}$ & $p$ \\
\hline & 1 & 2 & 3 & \\
\hline $\mathrm{TC}, \mu \mathrm{mol} / \mathrm{l}$ & $6.79 \pm 0.627$ & $8.04 \pm 1.746$ & $12.00 \pm 5.344$ & 0.006 \\
\hline $\mathrm{LDL}, \mu \mathrm{mol} / \mathrm{l}$ & $4.32 \pm 0.45435$ & $5.40 \pm 0.973$ & $7.24 \pm 1.447$ & 0.001 \\
\hline $\mathrm{HDL}, \mu \mathrm{mol} / \mathrm{l}$ & $1.52 \pm 0.431$ & $1.45 \pm 0.457$ & $1.15 \pm 0.578$ & 0.713 \\
\hline $\mathrm{TG}, \mu \mathrm{mol} / \mathrm{l}$ & $1.81 \pm 1.123$ & $2.46 \pm 3.245$ & $5.80 \pm 6.141$ & 0.240 \\
\hline Sphingosine, $\mathrm{ng} / \mathrm{ml}$ & $50.14 \pm 62.409$ & $83.59 \pm 70.774$ & $144.36 \pm 107.863$ & $\begin{array}{c}0.051 \\
\left.{ }^{*} 0.010 \text { (groups } 1 \text { and } 3\right)\end{array}$ \\
\hline Sphinganine, $\mathrm{ng} / \mathrm{ml}$ & $0.752 \pm 0.3713$ & $0.895 \pm 0.5841$ & $1.663 \pm 1.4619$ & 0.142 \\
\hline Galactosylceramide, ng/ml & $55.48 \pm 29.867$ & $66.60 \pm 43.291$ & $76.95 \pm 25.626$ & 0.473 \\
\hline \multicolumn{5}{|c|}{ Sphingomyelines } \\
\hline SM $18: 1 / 16: 0, \mu \mathrm{g} / \mathrm{ml}$ & $18997.6 \pm 13203.93$ & $15407.2 \pm 7769.07$ & $9557.6 \pm 2435.11$ & 0.274 \\
\hline $\mathrm{SM} 18: 1 / 16: 1, \mu \mathrm{g} / \mathrm{ml}$ & $1893.9 \pm 714.16$ & $1861.1 \pm 1642.95$ & $2208.3 \pm 1071.19$ & 0.432 \\
\hline $\mathrm{SM} 18: 1 / 18: 0, \mu \mathrm{g} / \mathrm{ml}$ & $3646.2 \pm 2447.91$ & $3322.6 \pm 1981.05$ & $2392.6 \pm 1758.81$ & 0.629 \\
\hline SM $18: 1 / 18: 1, \mu \mathrm{g} / \mathrm{ml}$ & $6138.8 \pm 4915.11$ & $5605.4 \pm 2747.14$ & $7240.6 \pm 3716.52$ & 0.806 \\
\hline SM $18: 1 / 20: 0, \mu \mathrm{g} / \mathrm{ml}$ & $19573.6 \pm 9198.49$ & $22693.9 \pm 15985.31$ & $24874.3 \pm 6191.24$ & 0.525 \\
\hline SM $18: 1 / 20: 1, \mu \mathrm{g} / \mathrm{ml}$ & $55331.1 \pm 34643.17$ & $55612.7 \pm 32720.49$ & $45554.0 \pm 17549.55$ & 0.924 \\
\hline SM $18: 1 / 22: 0, \mu \mathrm{g} / \mathrm{ml}$ & $6484.3 \pm 3692.833$ & $7141.1 \pm 2842.95$ & $10927.6 \pm 4151.37$ & 0.028 \\
\hline SM $18: 1 / 22: 1, \mu \mathrm{g} / \mathrm{ml}$ & $407.4 \pm 191.59$ & $416.9 \pm 211.78$ & $478.6 \pm 143.01$ & 0.721 \\
\hline SM $18: 1 / 24: 0, \mu \mathrm{g} / \mathrm{ml}$ & $1759.7 \pm 1613.16$ & $2155.4 \pm 1063.40$ & $1728.0 \pm 337.634$ & 0.328 \\
\hline $\mathrm{SM} 18: 1 / 24: 1, \mu \mathrm{g} / \mathrm{ml}$ & $6095.1 \pm 3364.35$ & $4835.2 \pm 2611.45$ & $4711.3 \pm 1018.43$ & 0.569 \\
\hline \multicolumn{5}{|c|}{ Ceramides } \\
\hline C $18: 0, \mu \mathrm{g} / \mathrm{ml}$ & $3.70 \pm 8.820$ & $6.04 \pm 9.740$ & $0.018 \pm 0.186$ & 0.513 \\
\hline C $20: 0, \mu \mathrm{g} / \mathrm{ml}$ & $224.70 \pm 655.577$ & $240.60 \pm 431.668$ & $367.67 \pm 144.417$ & 0.075 \\
\hline $\mathrm{C} 20: 1, \mu \mathrm{g} / \mathrm{ml}$ & $85.10 \pm 124.969$ & $98.00 \pm 229.133$ & $698.67 \pm 1138.155$ & 0.019 \\
\hline C $22: 0, \mu \mathrm{g} / \mathrm{ml}$ & $149.60 \pm 347.728$ & $75.96 \pm 71.642$ & $221.33 \pm 170.365$ & 0.100 \\
\hline C $22: 1, \mu \mathrm{g} / \mathrm{ml}$ & $77.00 \pm 82.254$ & $60.80 \pm 111.859$ & $714.67 \pm 1118.787$ & 0.003 \\
\hline $\mathrm{C} 24: 0, \mu \mathrm{g} / \mathrm{ml}$ & $587.80 \pm 200.069$ & $737.96 \pm 354.259$ & $782.00 \pm 357.669$ & 0.598 \\
\hline C $24: 1, \mu \mathrm{g} / \mathrm{ml}$ & $206.20 \pm 77.150$ & $313.08 \pm 254.952$ & $465.67 \pm 457.362$ & 0.546 \\
\hline C $18: 0 / C 24: 0, \mu \mathrm{g} / \mathrm{ml}$ & $0.0043 \pm 0.00938$ & $0.0079 \pm 0.01275$ & $0.0000 \pm 0.00000$ & 0.963 \\
\hline $\mathrm{C} 24: 1 / \mathrm{C} 24: 0, \mu \mathrm{g} / \mathrm{ml}$ & $0.3678 \pm 0.13805$ & $0.4600 \pm 0.35776$ & $0.5124 \pm 0.29631$ & 0.675 \\
\hline
\end{tabular}

Note: Kruskal-Wallis test. 
acute myocardial infarction, acute stroke, diabetes mellitus, secondary dislipidemia. The study did not include patients who received lipid-lowering therapy at the time of the examination.

In the beginning of the study 16 patients had arterial hypertension (45.7\%), 10 patients had coronary heart disease $(28.6 \%)$ and one patient had peripheral artery disease (2.9\%). Nineteen patients (54.3\%) had significant family history of cardiovascular diseases. Nine patients (25.7\%) smoked in their past but stopped smoking before inclusion in the study, 8 patients smoked at the moment of inclusion in the study (22.9\%)

The familial hypercholesterolemia $(\mathrm{FH})$ probability was evaluated using the Dutch Lipid Clinic Network Score. In 10 patients the probability of $\mathrm{FH}$ was low (score 1-2), 22 patients had possible FH (score 3-5). Three patients had probable or definite $\mathrm{FH}$ (score 6 in 2 patients, score 9 in one patient).

Blood sampling for biochemical analysis and mass spectrometry was performed on the day the patients were included in the study (in the morning on an empty stomach, after a 12-hour fast). Blood was taken from the cubital vein into sterile
Vakutainer tubes. Serum was obtained by blood centrifuging at a speed of $3000 \mathrm{rpm}$ for 15 minutes. Parameters with the following reference values were defined: total cholesterol (TC, 2.0-5.2 mmol/l), low-density lipoprotein cholesterol (LDL-C, up to $3.3 \mathrm{mmol} / \mathrm{l}$ ), high-density lipoprotein cholesterol (HDL-C, 0.91-1.56 mmol/l), blood serum triglycerides (TG, 0.50-1.70 $\mathrm{mmol} / \mathrm{l})$. To determine the parameters of serum, the CLIMA MC-15 biochemical analyzer was used (RAL; Spain).

Lipids were extracted from plasma in accordance with Bligh and Dyer Procedure [6]. Mass-spectrometry of molecular species of sphingomyelins, ceramides and sphingoid bases (sphingosine and sphinganine), as well as galactosylceramides, was performed using the TSQ Endura Triple Quadrupole Mass Spectrometer (Thermo Fisher Scientific; Germany) working in the MMP mode. The pressure at the collision cell was 1.5 mTorr. The resolution on Q1 and Q3 was 1.2 Da.

Ceramides: fragmentation of the protonated and dehydrated molecules was carried out at the energy of $25 \mathrm{eV}$ down to ion with $\mathrm{m} / \mathrm{z}$ 264.4 Da, the dwell time was $25 \mathrm{~ms}$.

Table 2. Blood lipids and sphingolipids in patients with family history and in patients without family history

\begin{tabular}{|c|c|c|c|}
\hline Parameters & No family history $(n=16)$ & Family history $(n=19)$ & $p$ \\
\hline $\mathrm{TC}, \mu \mathrm{mol} / \mathrm{l}$ & $8.11 \pm 1.142$ & $7.35 \pm 1.881$ & 0.026 \\
\hline LDL, $\mu \mathrm{mol} / \mathrm{l}$ & $5.49 \pm 1.063$ & $4.75 \pm 0.820$ & 0.039 \\
\hline $\mathrm{HDL}, \mu \mathrm{mol} / \mathrm{l}$ & $1.63 \pm 0.352$ & $1.32 \pm 0.479$ & 0.034 \\
\hline $\mathrm{TG}, \mu \mathrm{mol} / \mathrm{l}$ & $1.91 \pm 1.119$ & $2.57 \pm 3.712$ & 0.845 \\
\hline Sphingosine, $\mathrm{ng} / \mathrm{ml}$ & $65.31 \pm 55.298$ & $82.37 \pm 84.841$ & 0.021 \\
\hline Sphinganine, $\mathrm{ng} / \mathrm{ml}$ & $0.25 \pm 0.447$ & $0.47 \pm 0.612$ & 0.062 \\
\hline Galactosylceramide, $\mathrm{ng} / \mathrm{ml}$ & $59.38 \pm 46.989$ & $67.00 \pm 33.579$ & 0.123 \\
\hline \multicolumn{4}{|c|}{ Sphingomyelines } \\
\hline $\mathrm{SM} 18: 1 / 16: 0, \mu \mathrm{g} / \mathrm{ml}$ & $15812.5 \pm 8874.74$ & $16142.37 \pm 10210.772$ & 0.678 \\
\hline $\mathrm{SM} 18: 1 / 16: 1, \mu \mathrm{g} / \mathrm{ml}$ & $1703.38 \pm 1153.149$ & $2079.74 \pm 1637.244$ & 0.635 \\
\hline $\mathrm{SM} 18: 1 / 18: 0, \mu \mathrm{g} / \mathrm{ml}$ & $3446.00 \pm 2012.195$ & $3115.37 \pm 1651.906$ & 0.942 \\
\hline SM $18: 1 / 18: 1, \mu \mathrm{g} / \mathrm{ml}$ & $6066.06 \pm 4210.684$ & $5388.68 \pm 2755.342$ & 0.862 \\
\hline $\mathrm{SM} 18: 1 / 20: 0, \mu \mathrm{g} / \mathrm{ml}$ & $21605.00 \pm 6986.063$ & $22197.89 \pm 18558.786$ & 0.756 \\
\hline SM $18: 1 / 20: 1, \mu \mathrm{g} / \mathrm{ml}$ & $57836.31 \pm 37448.414$ & $51584.74 \pm 29461.884$ & 0.684 \\
\hline $\mathrm{SM} 18: 1 / 22: 0, \mu \mathrm{g} / \mathrm{ml}$ & $8366.13 \pm 3752.568$ & $8090.74 \pm 2977.416$ & 0.862 \\
\hline $\mathrm{SM} 18: 1 / 22: 1, \mu \mathrm{g} / \mathrm{ml}$ & $387.56 \pm 224.592$ & $441.26 \pm 183.190$ & 0.672 \\
\hline SM $18: 1 / 24: 0, \mu \mathrm{g} / \mathrm{ml}$ & $1809.31 \pm 983.979$ & $2218.1 \pm 1409.971$ & 0.584 \\
\hline $\mathrm{SM} 18: 1 / 24: 1, \mu \mathrm{g} / \mathrm{ml}$ & $5398.19 \pm 2713.511$ & $5094.32 \pm 2995.497$ & 0.682 \\
\hline \multicolumn{4}{|c|}{ Ceramides } \\
\hline $\mathrm{C} 18: 0, \mu \mathrm{g} / \mathrm{ml}$ & $6.31 \pm 10.163$ & $4.58 \pm 8.946$ & 0.213 \\
\hline C $20: 0, \mu \mathrm{g} / \mathrm{ml}$ & $78.56 \pm 150.510$ & $391.21 \pm 629.556$ & 0.021 \\
\hline C $20: 1, \mu \mathrm{g} / \mathrm{ml}$ & $57.38 \pm 108.836$ & $121.32 \pm 257.882$ & 0.010 \\
\hline C $22: 0, \mu \mathrm{g} / \mathrm{ml}$ & $60.19 \pm 64.744$ & $130.21 \pm 252.256$ & 0.040 \\
\hline C $22: 1, \mu \mathrm{g} / \mathrm{ml}$ & $47.75 \pm 52.003$ & $77.16 \pm 133.153$ & 0.252 \\
\hline C $24: 0, \mu \mathrm{g} / \mathrm{ml}$ & $726.69 \pm 334.931$ & $622.16 \pm 255.175$ & 0.572 \\
\hline C $24: 1, \mu \mathrm{g} / \mathrm{ml}$ & $324.25 \pm 264.550$ & $247.05 \pm 181.903$ & 0.457 \\
\hline $\mathrm{C} 18: 0 / \mathrm{C} 24: 0, \mu \mathrm{g} / \mathrm{ml}$ & $0.0072 \pm 0.01166$ & $0.0067 \pm 0.01235$ & 0.323 \\
\hline $\mathrm{C} 24: 1 / \mathrm{C} 24: 0, \mu \mathrm{g} / \mathrm{ml}$ & $0.4730 \pm 0.37832$ & $0.4078 \pm 0.24104$ & 0.872 \\
\hline
\end{tabular}

Note: Mann-Whitney test. 
Sphingomyelines: fragmentation of the protonated molecules was performed at the energy of $25 \mathrm{eV}$ down to ion with $\mathrm{m} / \mathrm{z}$ 184.1 Да, the dwell time was $25 \mathrm{~ms}$.

Sphingosine and its deuterated standard (d7, Avanti; USA): fragmentation of the protonated molecules was carried out at the energy of $12.5 \mathrm{eV}$ down to ions with $\mathrm{m} / \mathrm{z} 264.4$ and 259.3 Da respectively. The dwell time was $25 \mathrm{~ms}$.

Sphinganine: fragmentation of the protonated molecule was performed at the energy of $12.5 \mathrm{eV}$ down to ion with $\mathrm{m} / \mathrm{z}$ 266.4 Да, the dwell time was $50 \mathrm{~ms}$.

Galactosylceramide $\mathrm{d} 18: 1 / 18: 0:[\mathrm{M}+\mathrm{H}]^{+}$ion with a mass of $728.5 \mathrm{Da}$

The following parameters of the ionization source were used: heater temperature $300^{\circ} \mathrm{C}$, capillary temperature $340^{\circ} \mathrm{C}$, sheath gas flow 45 arb, auxiliary gas flow 13 arb, sweep gas flow 1 arb.

Sphingosine d7, sphinganine, sphingomyelin d18 : 1/16 : 0 , sphingomyelin d18:1/18:0, ceramide d18:1/16:0, ceramide d18 $: 1 / 18: 1$, ceramide d18 $: 1 / 18: 0$, ceramide d18 $: 1 / 24: 1$, ceramide d18:1/24:0 and galactosylceramide d18:1/18:0 (Avanti; USA) were used as standards.

\section{Chromatography}

Chromatography was performed using the Ultimate 3000 system (Thermo Fisher Scientific; Germany) and Eclipse Plus C8 column $3.0 \times 150 \mathrm{~mm}$ (Agilent; USA), the particle size was $3.5 \mu \mathrm{m}$. The temperature was $50{ }^{\circ} \mathrm{C}$, and the flow rate was $400 \mu \mathrm{l} / \mathrm{min}$.

When determining sphingosine, ceramides and sphingomyelin, the following mobile phases were used: phase A, water $+0.1 \%$ (v.v.) formic acid, phase B, methanol $+0.1 \%$ (v.v.) formic acid $(0.7$ minutes $55 \%$ of phase B, $100 \%$ of phase B up to 6.7 minutes, $100 \%$ of phase $B$ up to $12^{\text {th }}$ minute, $55 \%$ of phase $B$ up to $1-17^{\text {th }}$ minute, $55 \%$ of phase $B$ up to 13 th minute).

When determining sphinganine, the following mobile phases were used: фраза A, water $+0.1 \%$ (v.v.) formic acid, phase B, $50 \%$ methanol $+50 \%$ acetonitrile $+0.1 \%$ (v.v.) formic acid $(1.5$ minutes $20 \%$ of phase B, $100 \%$ of phase B up to 3.2 minutes, $100 \%$ of phase B up to 6.7 minutes, $20 \%$ of phase B up to 7.7 minutes, $20 \%$ of phase $B$ up to 10 th minute).

\section{Data processing}

The relative content of ceramides was evaluated using external calibration (method of standard addition). The Ceramide Porcine Brain 860052P ceramide mixture (Avanti; USA) was

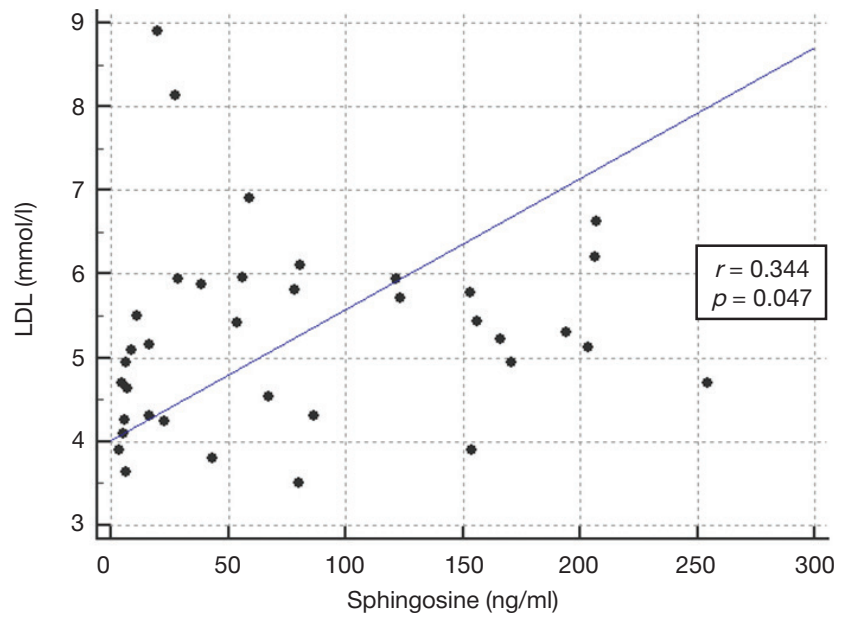

Fig. 1. Correlation of $L D L$ and blood sphingosine level used for calibration with $50 \%$ of Cer d18 : $1 / 18: 0$ and $20 \%$ of Cer d18:1/24:1. The calculation was based on the sum of peak areas of the MMP transitions $\mathrm{MH}^{+} \rightarrow \mathrm{m} / \mathrm{z}$ 264.4 Da and $\left(\mathrm{MH}-\mathrm{H}_{2} \mathrm{O}\right)^{++} \rightarrow \mathrm{m} / \mathrm{z} 264.4 \mathrm{Da}$.

When determining sphingomyelines, the Sphingomielin Porcine Brain 860062P mixture (Avanti; USA) and sphingomyelines d18 : 1/16:0, d18:1/18:0 (Avanti; USA) were used for calibration. The sum of peak areas of the MRM transitions $\mathrm{MH}^{+} \rightarrow \mathrm{m} / \mathrm{z}$ 184.1 Da was used for calculation.

The sphingosine d18: 1 content was determined by internal calibration (internal standard method, the standard was D-erythrosphingosine d7, Sigma; USA) using the sum of peak areas of the MMP transitions $\left(\mathrm{m} / \mathrm{z} 300^{+} \rightarrow \mathrm{m} / \mathrm{z} 264.4\right.$ Da for non-deuterated and $\mathrm{m} / \mathrm{z} 307^{+} \rightarrow \mathrm{m} / \mathrm{z} 259.3$ Da for deuterated sphingosine).

The sphinganine d18: 0 content was determined by external calibration (the standard was DL-erythro-dihidrosphingosine, Sigma; USA) using the sum of peak areas of the MMP transitions $\left(\mathrm{m} / \mathrm{z} 302^{++} \rightarrow \mathrm{m} / \mathrm{z} 266 \mathrm{Da}\right)$

\section{Statistical analysis}

Statistical analysis was carried out using the SPSS software, version 23.0 (IBM; USA). Quantitative variables were presented as mean with standard deviation. All variables were checked for compliance with normal distribution using the Shapiro-Wilk test. The distribution of all quantitative variables was different from normal. The significance of differences for two independent samples was evaluated using the Mann-Whitney test, and for three of more samples using the Kruskal-Wallis test. The significance of correlations was determined using the Sperman rank correlation test. The differences were considered significant when $p<0.05$.

\section{RESULTS}

Comparison of blood lipids and sphingolipids was carried out in groups of patients with different probability of family hyperlipidemia (Table 1).

Higher level of TC and LDL was observed in patients with $\mathrm{FH}$. In addition, in patients with $\mathrm{FH}$, a tendency was observed to sphingosine level increase compared with a group of patients having a low probability of $\mathrm{FH}(p<0.05)$.

In patients with $\mathrm{FH}$, an increase in the proportion of longchain sphingomyelin SM $18: 1 / 22$ : 0 was noted, as well as a significant increase in the level of long chain ceramides, C $20: 1$ and C $22: 1$. No significant differences of $C 18: 0 / C 24: 0$ and C $24: 1 / C 24: 0$ ratios were revealed.

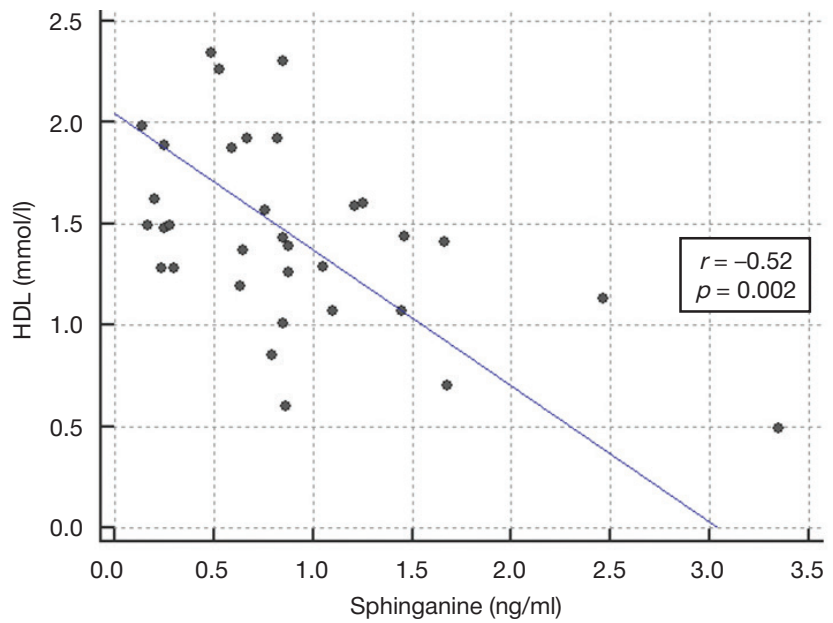

Fig. 2. Correlation of HDL and blood sphinganine level 
Table 3. Correlation of blood lipids, sphingomyeline and ceramide levels

\begin{tabular}{|c|c|c|c|c|c|}
\hline & & $\mathrm{TC}, \mu \mathrm{mol} / \mathrm{l}$ & $\mathrm{TG}, \mu \mathrm{mol} / \mathrm{l}$ & LDL-C, $\mu \mathrm{mol} / \mathrm{l}$ & $\mathrm{HDL}-\mathrm{C}, \mu \mathrm{mol} / \mathrm{l}$ \\
\hline \multirow[b]{2}{*}{$\mathrm{SM} 18: 1 / 16: 0, \mu \mathrm{g} / \mathrm{ml}$} & $r$ & 0.178 & -0.104 & 0.084 & 0.162 \\
\hline & $p$ & 0.307 & 0.564 & 0.636 & 0.391 \\
\hline \multirow[b]{2}{*}{$\mathrm{SM} 18: 1 / 16: 1, \mu \mathrm{g} / \mathrm{ml}$} & $r$ & 0.260 & -0.171 & 0.093 & 0.045 \\
\hline & $p$ & 0.132 & 0.341 & 0.602 & 0.813 \\
\hline \multirow[b]{2}{*}{$\mathrm{SM} 18: 1 / 18: 0, \mu \mathrm{g} / \mathrm{ml}$} & $r$ & 0.257 & -0.140 & 0.278 & 0.236 \\
\hline & $p$ & 0.135 & 0.439 & 0.111 & 0.210 \\
\hline \multirow[b]{2}{*}{$\mathrm{SM} 18: 1 / 18: 1, \mu \mathrm{g} / \mathrm{ml}$} & $r$ & -0.139 & -0.095 & -0.202 & 0.077 \\
\hline & $p$ & 0.426 & 0.597 & 0.251 & 0.686 \\
\hline \multirow[b]{2}{*}{$\mathrm{SM} 18: 1 / 20: 0, \mu \mathrm{g} / \mathrm{ml}$} & $r$ & $0.363^{*}$ & -0.015 & 0.184 & -0.110 \\
\hline & $p$ & 0.032 & 0.934 & 0.297 & 0.561 \\
\hline \multirow[b]{2}{*}{$\mathrm{SM} 18: 1 / 20: 1, \mu \mathrm{g} / \mathrm{ml}$} & $r$ & -0.101 & 0.111 & -0.098 & 0.334 \\
\hline & $p$ & 0.562 & 0.540 & 0.581 & 0.072 \\
\hline \multirow[b]{2}{*}{$\mathrm{SM} 18: 1 / 22: 0, \mu \mathrm{g} / \mathrm{ml}$} & $r$ & -0.017 & -0.313 & -0.155 & 0.165 \\
\hline & $p$ & 0.924 & 0.076 & 0.383 & 0.382 \\
\hline \multirow[b]{2}{*}{$\mathrm{SM} 18: 1 / 22: 1, \mu \mathrm{g} / \mathrm{ml}$} & $r$ & 0.082 & 0.146 & 0.125 & -0.187 \\
\hline & $p$ & 0.642 & 0.419 & 0.481 & 0.321 \\
\hline \multirow[b]{2}{*}{$\mathrm{SM} 18: 1 / 24: 0, \mu \mathrm{g} / \mathrm{ml}$} & $r$ & 0.048 & -0.183 & 0.100 & -0.254 \\
\hline & $p$ & 0.782 & 0.307 & 0.572 & 0.175 \\
\hline \multirow[b]{2}{*}{$\mathrm{SM} 18: 1 / 24: 1 \mu \mathrm{g} / \mathrm{ml}$} & $r$ & 0.217 & -0.297 & 0.148 & 0.046 \\
\hline & $p$ & 0.210 & 0.094 & 0.403 & 0.809 \\
\hline \multirow[b]{2}{*}{$\mathrm{C} 18: 0, \mu \mathrm{g} / \mathrm{ml}$} & $r$ & 0.104 & -0.041 & 0.105 & -0.104 \\
\hline & $p$ & 0.552 & 0.820 & 0.556 & 0.584 \\
\hline \multirow[b]{2}{*}{$\mathrm{C} 20: 0, \mu \mathrm{g} / \mathrm{ml}$} & $r$ & 0.055 & 0.141 & -0.003 & $-0.420^{*}$ \\
\hline & $p$ & 0.752 & 0.433 & 0.987 & 0.021 \\
\hline \multirow[b]{2}{*}{$\mathrm{C} 20: 1, \mu \mathrm{g} / \mathrm{ml}$} & $r$ & -0.177 & $0.447^{\star *}$ & $-0.425^{*}$ & $0.525^{\star \star}$ \\
\hline & $p$ & 0.310 & 0.009 & 0.012 & 0.003 \\
\hline \multirow[b]{2}{*}{$\mathrm{C} 22: 0, \mu \mathrm{g} / \mathrm{ml}$} & $r$ & 0.015 & 0.342 & 0.049 & $-0.429^{*}$ \\
\hline & $p$ & 0.932 & 0.052 & 0.783 & 0.018 \\
\hline \multirow[b]{2}{*}{$\mathrm{C} 22: 1, \mu \mathrm{g} / \mathrm{ml}$} & $r$ & 0.070 & 0.051 & -0.094 & -0.168 \\
\hline & $p$ & 0.689 & 0.776 & 0.598 & 0.374 \\
\hline \multirow[b]{2}{*}{$\mathrm{C} 24: 0, \mu \mathrm{g} / \mathrm{ml}$} & $r$ & $0.475^{\star *}$ & 0.100 & 0.334 & 0.008 \\
\hline & $p$ & 0.004 & 0.579 & 0.054 & 0.965 \\
\hline \multirow[b]{2}{*}{ C $24: 1, \mu \mathrm{g} / \mathrm{ml}$} & $r$ & $0.558^{* *}$ & 0.005 & $0.471^{* *}$ & 0.296 \\
\hline & $p$ & 0.000 & 0.976 & 0.005 & 0.112 \\
\hline
\end{tabular}

Note: $r$ - Spearman rank correlation; ${ }^{*}-p<0.005 ;{ }^{* *}-p<0.001$. 


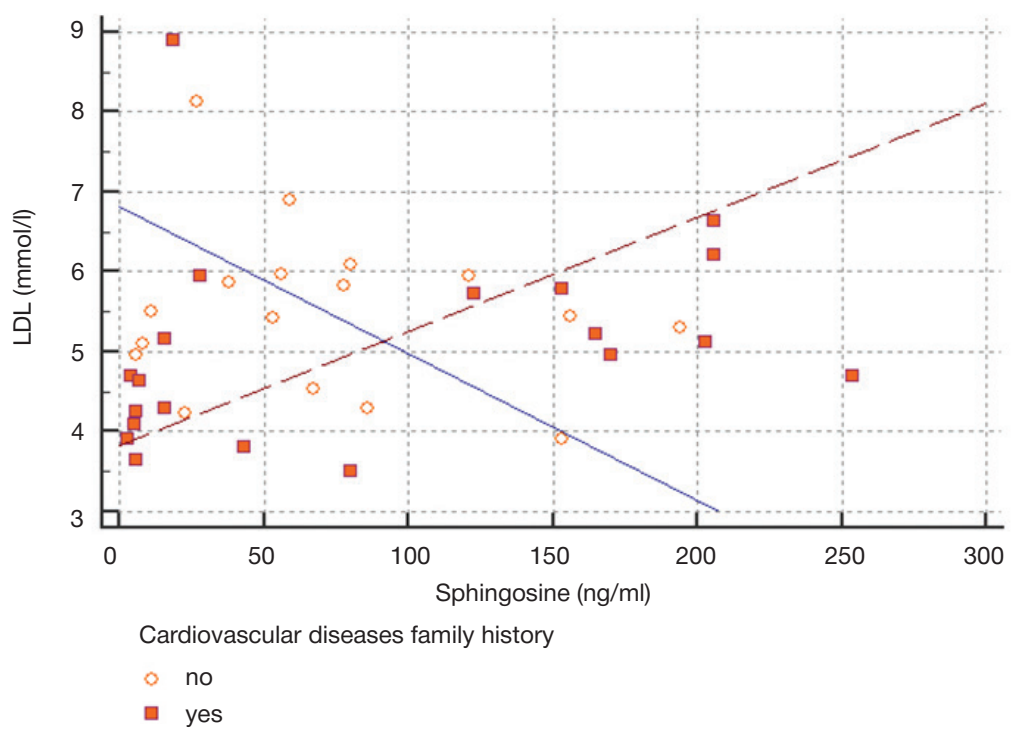

Fig. 3. Correlation of LDL and blood sphingosine level

We analyzed the relationship between the level of various lipids and sphingolipids and the presence of a significant family history in patients (Table 2). In patients with significant family history, the higher level of sphingosine and significantly higher level of ceramides C $20: 0$, C $20: 1$, C 22 : 0 were observed.

Positive correlation of LDL and sphingosine level was revealed (Fig. 1). In addition, it was possible to identify negative correlation of HDL and sphinganin (Fig. 2) and galactosylceramide levels $(r=-0.56 ; p=0.001)$. Correlation analysis of sphingomyelin fractions level and ceramides with classical lipid fractions is presented in Table 3. A positive correlation of the level of ceramides C $24: 0$ and C 24:1 with the TC and LDL level is noteworthy. For $\mathrm{C} 20$ : 0 ceramide, a positive correlation with the HDL and TG level and a negative correlation with LDL level were revealed. Negative correlation of the C22 : 0 ceramide level with the HDL level was determined.

We analyzed correlations between the level of classical lipids and sphingolipids in patients having a significant family history and in patients with no sifnificant family history. It is noteworthy, that a positive correlation between the level of LDL-C and sphingosine, revealed in the whole group, was of greater strength in patients with a significant family history $(r=0.536$; $p=0.022$ ). In patients with no significant family history, there was a negative correlation between LDL-C and sphingosine levels ( $r=-0.351 ; p=0.048$ ) (Fig. 3).

\section{DISCUSSION}

There are few studies of the sphingomyelins' and ceramides' profile in patients with family hyperlipidemia. The animal model of family hyperlipidemia associated with LDL receptor gene mutations demonstrated the significant increase of total sphingomyeline and C18:0 ceramide in homozygotes [7]. In our study we noted only the SM $18: 1 / 22: 0$ fraction and C20 : 1 ceramide increase.

It was shown that the level of ceramides is associated with other coronary heart disease risk factors (obesity and insulin resistance). It was believed that some ceramide fractions were able to stimulate the synthesis of pro-inflammatory cytokines (e.g., tumor necrosis factor) in case of increased consumption of saturated fat with food [8]. In patients after bariatric surgery, a decrease in the level of atherogenic sphinogomyelins and ceramides was observed earlier and to a much greater extent than weight loss, which correlated with a decrease in coronary risks [9].

It was found that in oxidized LDL the content of total sphingolipids and ceramides was significantly higher, which could be an evidence of the role of sphingolipids in destabilization of atherosclerotic plaque and coronary heart disease and other disorders' complications manifestation [10]. Sphingosine causes aggregation of $\mathrm{Cu}^{2+}$ peroxide vesicles and accelerates LDL peroxidation, making them more atherogenic. Long chain ceramides can serve as catalysts for said process. Ceramides with chain length C6, C8, C10 do not possess such activity. Sphinganine, on the opposite, blocks peroxidation processes [11]. In our study we noted the significant increase of sphingosine level in patients with definite family dislipidemia. There were no significant differences in the sphinganine level in patients with low and high probability of family hyperlipidemia.

ApoE gene polymorphism (2/3/4) is associated with the increase of ceramide pathogenic fractions which may be related with increased coronary heart disease risk in young people [12].

The value of ceramides C $16: 0$, C $22: 0$, C $24: 0$, C $24: 1$ in the carotid atherosclerosis pathogenesis in HIV patients was shown. For the long chain ceramides $C: 22$ and $C: 24$ a positive correlation with the TC and LDL level was determined [13]. Positive correlation of sphingomyelines SM d16:0/28 : 5, SM d18: 1/24: 1 and SM d18: 1/16: 0 with the TC and LDL level was revealed in the animal model of dislipidemia (ApoE-deficient mice). The level of said fractions in animals with hyperlipidemia was elevated. Sphingolipides of such kind are considered pro-atherogenic [14]. There is evidence that oxidative stress and lipotoxicity are associated precisely with an increase in the level of long chain ceramides, which, for example, becomes apparent in patients with insulin resistance [15]. In our study the SM $18: 1 / 22: 0$ sphingomyeline was increased in patients with definite/probable hyperlipidemia. Positive correlations of blood cholesterol with ceramides C24 : 0 , C24 : 1 level were revealed.

Our study had a number of limitations: single site study, small sample size, lack of data from large studies on the epidemiological relationship between detected changes in lipid component and cardiovascular events (heart attacks, strokes, cardiovascular death). 


\section{CONCLUSION}

Patients with definite/probable FH demonstrate not only high level of TC and LDL, but also the high level of pro-atherogenic sphingosine, sphingomyeline SM $18: 1 / 22: 0$, and long chain ceramides (C 20 : 1, C 22 : 1). The revealed lipidome features require further clarification of their clinical significance.
Lipidome changes may help to explain the mechanism of increasing the risk and early onset of atherosclerosis in said group of patients.

Positive correlation of sphingosine with the LDL level in patients with significant family history is the evidence of the importance of sphingosine as an additional risk factor associated with the family nature of the disease.

\section{References}

1. Matanes F, Twal WO, Hammad SM. Sphingolipids as biomarkers of disease. Adv Exp Med Biol. 2019; (1159): 109-38. DOI: 10.1007/978-3-030-21162-2 7.

2. Anroedh S, Hilvo M, Akkerhuis KM, Kauhanen D, Koistinen K, Oemrawsingh $\mathrm{R}$, et al. Plasma concentrations of molecular lipid species predict long-term clinical outcome in coronary artery disease patients. J Lipid Res. 2018; 59 (9): 1729-37. DOl: 10.1194/jlr.P081281.

3. Sutter I, Klingenberg R, Othman A, Rohrer L, Landmesser U, Heg D, et al. Decreased phosphatidylcholine plasmalogens - a putative novel lipid signature in patients with stable coronary artery disease and acute myocardial infarction. Atherosclerosis. 2016; (246): 130-40. DOI: 10.1016/j.atherosclerosis.2016.01.003.

4. Ng TW, Ooi EM, Watts GF, Chan DC, Meikle PJ, Barrett PH. Association of plasma ceramides and sphingomyelin with VLDL apoB-100 fractional catabolic rate before and after rosuvastatin treatment. J Clin Endocrinol Metab. 2015; 100 (6): 2497-501. DOI: 10.1210/jc.2014-4348. PubMed PMID: 25816050.

5. Tarasov K, Ekroos K, Suoniemi M, Kauhanen D, Sylvänne T, Hurme R, et al. Molecular lipids identify cardiovascular risk and are efficiently lowered by simvastatin and PCSK9 deficiency. J Clin Endocrinol Metab. 2014; 99 (1): E45-52. DOl:10.1210/jc.20132559. PubMed PMID: 24243630; PubMed Central PMCID: PMC3928964

6. Bligh EG, Dyer WJ. A rapid method of total lipid extraction and purification. Can J Biochem Physiol. 1959; 37 (8): 911-7.

7. Hoogendoorn A, den Hoedt S, Hartman EMJ, Krabbendam-Peters I, Te Lintel Hekkert M, van der Zee L, et al. Variation in coronary atherosclerosis severity related to a distinct LDL (Low-Density Lipoprotein) profile: findings from a familial hypercholesterolemia pig model. Arterioscler Thromb Vasc Biol. 2019; 39 (11): 2338-52. DOI:10.1161/ATVBAHA.119.313246.

8. Sokolowska E, Blachnio-Zabielska A. The role of ceramides in

\section{Литература}

1. Matanes F, Twal WO, Hammad SM. Sphingolipids as biomarkers of disease. Adv Exp Med Biol. 2019; (1159): 109-38. DOI: 10.1007/978-3-030-21162-2 7.

2. Anroedh S, Hilvo M, Akkerhuis KM, Kauhanen D, Koistinen K, Oemrawsingh $\mathrm{R}$, et al. Plasma concentrations of molecular lipid species predict long-term clinical outcome in coronary artery disease patients. J Lipid Res. 2018; 59 (9): 1729-37. DOI: 10.1194/jlr.P081281

3. Sutter I, Klingenberg R, Othman A, Rohrer L, Landmesser U, Heg D, et al. Decreased phosphatidylcholine plasmalogens - a putative novel lipid signature in patients with stable coronary artery disease and acute myocardial infarction. Atherosclerosis. 2016; (246): 130-40. DOI: 10.1016/j.atherosclerosis.2016.01.003.

4. Ng TW, Ooi EM, Watts GF, Chan DC, Meikle PJ, Barrett PH. Association of plasma ceramides and sphingomyelin with VLDL apoB-100 fractional catabolic rate before and after rosuvastatin treatment. J Clin Endocrinol Metab. 2015; 100 (6): 2497-501. DOI: 10.1210/jc.2014-4348. PubMed PMID: 25816050.

5. Tarasov K, Ekroos K, Suoniemi M, Kauhanen D, Sylvänne T, Hurme R, et al. Molecular lipids identify cardiovascular risk and are efficiently lowered by simvastatin and PCSK9 deficiency. J Clin Endocrinol Metab. 2014; 99 (1): E45-52. DOI:10.1210/jc.2013-

insulin resistance. Front Endocrinol (Lausanne). 2019; (10): 577. DOI: 10.3389/fendo.2019.00577.

9. Kayser BD, Lhomme M, Dao MC, Ichou F, Bouillot JL, Prifti E, et al. Serum lipidomics reveals early differential effects of gastric bypass compared with banding on phospholipids and sphingolipids independent of differences in weight loss. Int $\mathrm{J}$ Obes (Lond). 2017; 41 (6): 917-25. DOI: 10.1038/ijo.2017.63.

10. Paul A, Lydic TA, Hogan R, Goo YH. Cholesterol acceptors regulate the lipidome of macrophage foam cells. Int $\mathrm{J}$ Mol Sci. 2019; 20 (15): E3784-801. DOI: 10.3390/ijms20153784.

11. Jiménez-Rojo N, Viguera AR, Collado MI, Sims KH, Constance C, Hill KS et al. Sphingosine induces the aggregation of iminecontaining peroxidized vesicles. Biochim Biophys Acta. 2014; 1838 (8): 2071-7. DOl: 10.1016/j.bbamem.2014.04.028.

12. Karjalainen JP, Mononen N, Hutri-Kähönen N, Lehtimäki M, Hilvo $M(4)$, Kauhanen D, et al. New evidence from plasma ceramides links apoE polymorphism to greater risk of coronary artery disease in Finnish adults. J Lipid Res. 2019; 60 (9): 1622-9. DOI: 10.1194/ jlr.M092809.

13. Zhao W, Wang X, Deik AA, Hanna DB, Wang T, Haberlen SA et al. Elevated plasma ceramides are associated with antiretroviral therapy use and progression of carotid artery atherosclerosis in HIV infection. Circulation. 2019; 139 (17): 2003-11. DOl: 0.1161/ CIRCULATIONAHA.118.037487.

14. Chen Y, Wen S, Jiang M, Zhu Y, Ding L, Shi H, et al. Atherosclerotic dyslipidemia revealed by plasma lipidomics on ApoE-/- mice fed a high-fat diet. Atherosclerosis. 2017; (262): 78-86. DOI: 10.1016/j. atherosclerosis.2017.05.010.

15. Law BA, Liao X, Moore KS, Southard A, Roddy P, Ji R, et al. Lipotoxic very-long-chain ceramides cause mitochondrial dysfunction, oxidative stress, and cell death in cardiomyocytes. FASEB $\mathrm{J}$. 2018; 32 (3): 1403-16. DOl: 10.1096/fj.201700300R. PubMed PMID: 29127192; PubMed Central PMCID: PMC5892719.

2559. PubMed PMID: 24243630; PubMed Central PMCID: PMC3928964.

6. Bligh EG, Dyer WJ. A rapid method of total lipid extraction and purification. Can J Biochem Physiol. 1959; 37 (8): 911-7.

7. Hoogendoorn A, den Hoedt S, Hartman EMJ, Krabbendam-Peters I, Te Lintel Hekkert M, van der Zee L, et al. Variation in coronary atherosclerosis severity related to a distinct LDL (Low-Density Lipoprotein) profile: findings from a familial hypercholesterolemia pig model. Arterioscler Thromb Vasc Biol. 2019; 39 (11): 2338-52. DOI:10.1161/ATVBAHA.119.313246.

8. Sokolowska E, Blachnio-Zabielska A. The role of ceramides in insulin resistance. Front Endocrinol (Lausanne). 2019; (10): 577. DOI: 10.3389/fendo.2019.00577.

9. Kayser BD, Lhomme M, Dao MC, Ichou F, Bouillot JL, Prifti E, et al. Serum lipidomics reveals early differential effects of gastric bypass compared with banding on phospholipids and sphingolipids independent of differences in weight loss. Int $\mathrm{J}$ Obes (Lond). 2017; 41 (6): 917-25. DOI: 10.1038/ijo.2017.63.

10. Paul A, Lydic TA, Hogan R, Goo YH. Cholesterol acceptors regulate the lipidome of macrophage foam cells. Int J Mol Sci. 2019; 20 (15): E3784-801. DOI: 10.3390/ijms20153784.

11. Jiménez-Rojo N, Viguera AR, Collado MI, Sims KH, Constance C, 


\section{ОРИГИНАЛЬНОЕ ИССЛЕДОВАНИЕ І ЛИПИДОЛОГИЯ}

Hill KS, et al. Sphingosine induces the aggregation of iminecontaining peroxidized vesicles. Biochim Biophys Acta. 2014; 1838 (8): 2071-7. DOI: 10.1016/j.bbamem.2014.04.028.

12. Karjalainen JP, Mononen N, Hutri-Kähönen N, Lehtimäki M, Hilvo $M(4)$, Kauhanen D, et al. New evidence from plasma ceramides links apoE polymorphism to greater risk of coronary artery disease in Finnish adults. J Lipid Res. 2019; 60 (9): 1622-9. DOI: 10.1194/ jlr.M092809.

13. Zhao W, Wang $X$, Deik AA, Hanna DB, Wang T, Haberlen SA, et al. Elevated plasma ceramides are associated with antiretroviral therapy use and progression of carotid artery atherosclerosis in
HIV infection. Circulation. 2019; 139 (17): 2003-11. DOI: 0.1161/ CIRCULATIONAHA.118.037487.

14. Chen Y, Wen S, Jiang M, Zhu Y, Ding L, Shi H, et al. Atherosclerotic dyslipidemia revealed by plasma lipidomics on ApoE-/- mice fed a high-fat diet. Atherosclerosis. 2017; (262): 78-86. DOI: 10.1016/j. atherosclerosis.2017.05.010.

15. Law BA, Liao X, Moore KS, Southard A, Roddy P, Ji R, et al. Lipotoxic very-long-chain ceramides cause mitochondrial dysfunction, oxidative stress, and cell death in cardiomyocytes. FASEB J. 2018; 32 (3): 1403-16. DOI: 10.1096/fj.201700300R. PubMed PMID: 29127192; PubMed Central PMCID: PMC5892719. 